\title{
Financial Management of Construction Companies
}

\author{
Jiř́ Kusák ${ }^{1}$ and Eva Vítková ${ }^{2}$ \\ ${ }^{1}$ Brno University of Technology, Faculty of Civil Engineering, Institute of Structural Economy and \\ Management, Veveř́ 331/95, Brno, Czech Republic, jiri.kusak@vutbr.cz \\ ${ }^{2}$ Brno University of Technology, Faculty of Civil Engineering, Institute of Structural Economy and \\ Management, Veveř́ 331/95, Brno, Czech Republic, vitkova.e@fce.vutbr.cz
}

\begin{abstract}
The objective of financial management of construction companies is to generate profit and provide financial stability. Financial stability is provided by managing the amount of both fixed and current assets, the amount of equity and external capital. Therefore, in order to reach the objective of financial management, it is necessary to comply with the basic financial rules. In the framework of nationwide analyses of economic indicators for different industries, there is data published on the website of the Ministry of Industry and Trade, which, however, apply to all construction companies. For this reason, the authors of the article focused on individual subcategories of construction companies (small, medium and large), which are defined by turnover, assets and number of employees. The research studied whether these subcategories fulfil all or part of the basic financial rules, including the following rules: golden rule of risk equalization: the ratio of own and external resources should be in the ratio of 1:1, golden balance rule: fixed assets should be covered by long-term resources; golden "pari" rule: fixed assets should be covered by equity. The research also monitored the structure of assets, i.e. the ratio between fixed and current assets and was based on elementary methods of financial analysis (vertical and horizontal methods). The outputs of the paper will be further used for the next step of the research, which will focus on tax optimization of individual categories of construction companies in relation to financial management of fixed assets.
\end{abstract}

Keywords: Financial Management, Construction Companies, Basic Financial Rules, Vertical and Horizontal Methods, Financial Analysis.

\section{Introduction}

Financial management of companies, not exclusively construction companies, represent one component of important strategic management in terms of managing the entire economic development of the company. Financing is not only reflected in the indebtedness of the selected company and its liquidity, but also in providing cost-effectiveness, i.e. profitability. It is important to create a positive economic result for any viable company. This can be achieved by different financial resources. In general, the definition says that external sources of financing are always cheaper than own sources of financing (Srpová, Řehoř et al., 2010). The Ministry of Industry and Trade publishes quarterly, semi-annual and annual statistics on financial indicators for individual sectors. Financial indicators relate not only to the percentage share of fixed assets on total assets, external resources of financing on total liabilities, and other indicators resulting from the vertical analysis of financial statements, but also ratios such as liquidity of all three levels, return on equity, indebtedness and others. In these statistical surveys, the above-mentioned indicators are kept by industrial sectors. This means that the closest sector to this research is construction industry, which is further divided in these statistics 
into building construction, civil engineering and specialized construction activities. The total number of samples for the whole Czech Republic for these statistics was 85 companies. However, these statistics do not reflect the size of the company. The Accounting Act divides companies as accounting units into micro, small, medium and large according to their size, where the criteria for classification into a certain category are the amount of assets, the amount of turnover and the number of employees. For the above-mentioned reasons, the research was focused on the survey of selected financial indicators according to the categories corresponding to company sizes. The selected financial indicators for the research were mainly: the percentage share of fixed and current assets on total assets, percentage share of own and external capital (financial resources) on liabilities and other indicators that confirm basic financial rules for each size category of construction company doing business in the construction industry.

\section{Present State References}

Act No. 563/1991, on Accounting (1991) in Section 1b defines the categories of accounting unit sizes (companies) as micro, small, medium and large. This division is governed by the balance sheet data, at which the thresholds for the amount of assets, the total net annual turnover and the average annual number of employees are defined. EU Recommendation 2003/361/EC (2003) of 6 May 2003, published by the Ministry of Industry and Trade and the Office for the Protection of Competition, also defines the sizes of companies as micro, small and mediumsized companies. This definition, as well as the Accounting Act, deals with the amount of assets,

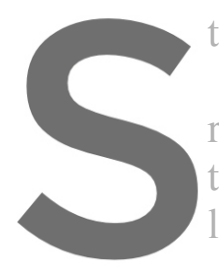
the total net turnover and the average number of employes.

Srpová and Řehoř related to time and states this definition it there long-term resources.

Another financial rule is the risk equalization rule (Srpová,

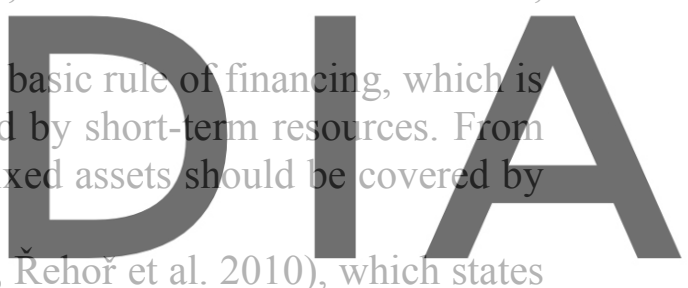
that the ratio of own and external resources should be 1:1, over time the ratio has changed to Register fo.k freq at https//WWW.scipedia.com to download the version without the watermark

In her book, Kislinger (2007) defines the golden "pari" rule which states that fixed assets should be financed by company's own resource.

Biliavska, Mizunska and Yurii (2019) assessed the real financial status of both, identifying possible ways to improve the management of the existing assets of the two companies and the companies' compliance with the golden rule of financing was analysed.

In the second paper, Biliavska, Mizunska and Kovalchuk (2019) assessed liquidity of two companies and the basic problems of the unstable financial condition of the companies determined with the help of calculated coefficients and the steps expedient for stabilization of the situation suggested.

Viszlai (2015) in his paper analysed structure of assets and capital structure in different forest companies and searched for differences between the model situation and real conditions. $\mathrm{He}$ used three basic financial rules for assessing and analysing assets and capital structure - golden rule of financing, current ratio and one to one rule.

Isik and Meric (2009) in their paper challenged the proposition that the golden rule of public sector borrowing its consistent with the principle of intertemporal allocative efficiency.

Groneck (2010) compared growth and welfare effects of various budget rules within an 
endogenous growth model with productive public capital, utility enhancing public consumption and public debt. He found out that introducing a fixed deficit regime does not affect the long run growth rate compared to a balanced budget while establishing a golden rule results in higher growth.

Konečný (2013) in the paper studies whether the golden rules of financing are (or are not) respected depending on financial strategy in the sub-phases of the company life cycle.

\section{Methodology}

From a methodological point of view, the research was run on 17 samples for all categories of construction companies. The principle that at least 5 samples should fall within a given category has always been observed. In order to obtain input data from public sources, just the following categories were taken into account: small, medium and large. Financial statements from the website www.justice.cz, where financial statements for each accounting period are published, were used as input data. The period 2009-2017 was taken as the monitored period.

Individual categories of company sizes are defined by Act No. 563/1991 Coll., On Accounting, as follows:

\section{Small companies: total assets totalling at CZK 100,000,000, annual total net turnover of CZK 200,000,000, average number of employees 50; must not exceed at least 2 of the specified limits,}
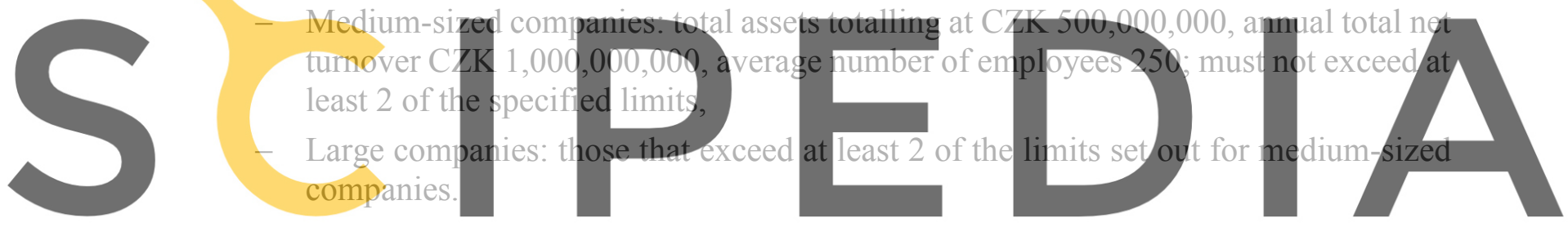

Financial indicators were processed using the basic method of financial analysis, namely

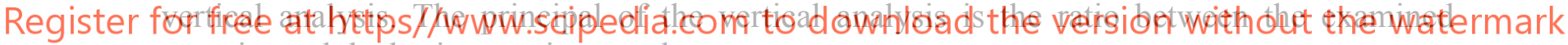
quantity and the basic quantity stated as a percentage.

Determination of percentage $=\frac{\text { researche quantity }}{\text { basic quantity }} * 100$

The basic financial rules for efficient and sound company management are based on three pillars:

$-\quad 1^{\text {st }}$ golden rule of risk equalization: the ratio of own and external resources should be $1: 1$,

- $2^{\mathrm{n}} \mathrm{d}$ golden balance rule: fixed assets should be covered by long-term resources,

- $3^{\text {rd }}$ golden "pari" rule: fixed assets should be covered by equity.

The Ministry of Industry and Trade (www.mpo.cz) in its statistical surveys and analytical materials lists only some indicators that can be used for the golden rules of financing. These are the indicators that assess the first golden rule of risk equalization and the third golden "pari" rule. It is necessary to note that the resulting values represent only the construction sector, the resulting values of the statistical survey do not reflect company size in any way. In the monitored years, according to analyses by the Ministry of Industry and Trade, the annual 
percentages shares were as follows, see Tables 1 and 2.

Table 1. Ratio of own and external resources in the construction sector.

\begin{tabular}{ccccccccccc}
\hline Year & 2009 & 2010 & 2011 & 2012 & 2013 & 2014 & 2015 & 2016 & 2017 & 2018 \\
\hline Own resources (\%) & 35.20 & 37.31 & 38.56 & 40.96 & 40.68 & 40.53 & 40.12 & 45.30 & 45.49 & 44.23 \\
\hline External resources (\%) & 63.14 & 60.91 & 59.65 & 57.34 & 36.32 & 31.75 & 58.33 & 53.02 & 53.09 & 54.39 \\
\hline
\end{tabular}

Table 2. Ratio of fixed and current assets in the construction sector.

\begin{tabular}{cccccccccccc}
\hline Year & 2009 & 2010 & 2011 & 2012 & 2013 & 2014 & 2015 & 2016 & 2017 & 2018 \\
\hline Fixed Assets (\%) & 27.93 & 30.44 & 32.17 & 29.93 & 33.04 & 33.61 & 34.37 & 33.78 & 33.71 & 32.78 \\
\hline Current assets (\%) & 71.21 & 68.93 & 67.09 & 69.12 & 66.17 & 65.80 & 65.08 & 65.74 & 65.71 & 66.75
\end{tabular}

The research therefore deals mainly with the differences in the individual golden rules of

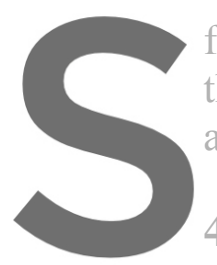
financing, which were the differences between th and values based on con

\section{Results}
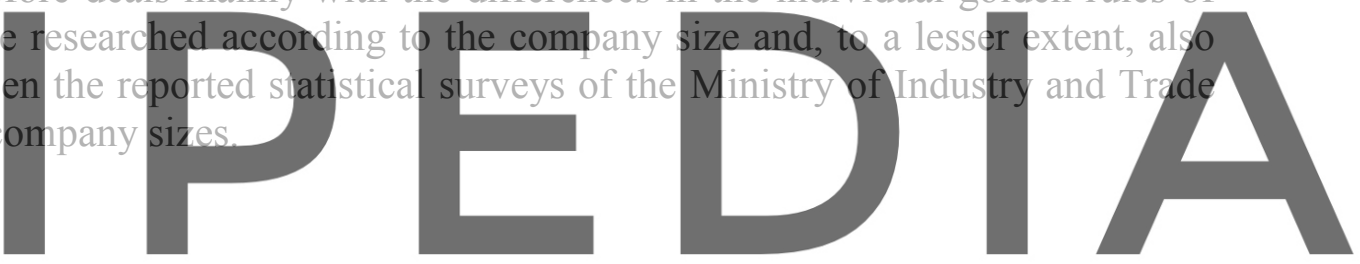

Following financial indicators were monitored within the research using the vertical method,

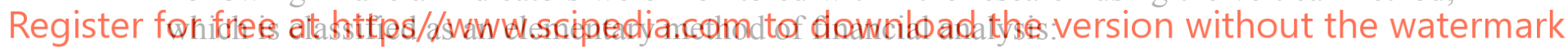

- own resources (equity)

- external resources

- fixed assets

- current assets

- long-term resources

- short-term resources

Within the individual golden rules, the research reached the following conclusions.

The first golden rule, which states that own resources of financing and external resources of financing should be in ratio of 1:1 and are evaluated by a nationwide statistical survey of the Ministry of Industry and Trade (see Table 1), was analysed according to the company size categories in the 2009-2017 period as follows, see Tables 3 and 4. 
Table 3. Representation of own resources in individual categories of companies.

\begin{tabular}{lcccccccccr}
\hline Year & 2009 & 2010 & 2011 & 2012 & 2013 & 2014 & 2015 & 2016 & 2017 & Average \\
\hline Small & 47.82 & 60.98 & 64.20 & 67.69 & 61.30 & 69.85 & 76.32 & 71.29 & 66.10 & 65.06 \\
\hline Medium & 53.94 & 55.71 & 47.67 & 47.84 & 49.37 & 46.03 & 45.98 & 42.11 & 42.04 & 47.85 \\
\hline Large & 28.33 & 29.15 & 29.84 & 29.79 & 29.08 & 29.18 & 29.24 & 26.25 & 30.28 & 29.02 \\
\hline Average & 43.36 & 48.61 & 47.24 & 48.44 & 46.58 & 48.35 & 50.51 & 46.55 & 46.14 & 47.31 \\
\hline
\end{tabular}

Table 4. Representation of external resources in individual categories of companies.

\begin{tabular}{lcccccccccc}
\hline Year & 2009 & 2010 & 2011 & 2012 & 2013 & 2014 & 2015 & 2016 & 2017 & Average \\
\hline Small & 52.18 & 39.02 & 34.15 & 32.18 & 38.25 & 29.86 & 23.51 & 28.51 & 32.96 & 34.51 \\
\hline Medium & 44.50 & 43.34 & 51.76 & 51.45 & 50.13 & 53.09 & 52.38 & 57.16 & 57.25 & 51.23 \\
\hline Large & 69.71 & 68.82 & 68.74 & 68.78 & 69.87 & 69.49 & 69.58 & 72.54 & 68.37 & 69.54 \\
\hline Average & 55.41 & 50.40 & 51.55 & 50.80 & 52.75 & 50.81 & 48.49 & 52.74 & 52.86 & 51.76 \\
\hline
\end{tabular}

It is clear from the above-mentioned values that if we take into account the average values of own and external resources for all companies, they almost reach the ratio 1:1, which would confirm the first golden rule. However, if the average values of individual categories of company sizes were analysed, it was found out that the golden rule of financing was not exactly observed in any case. The analysis shows that small companies finance their activities more

from their own resource more from external rese 70\%. The medium-size c difference was $2 \%$, which Table 3 and Table 4 wi

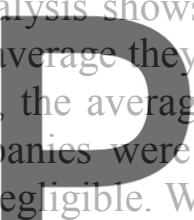

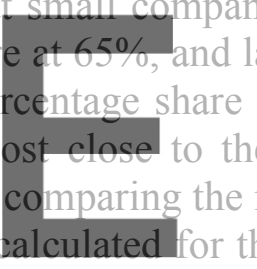

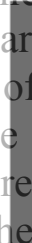

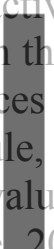

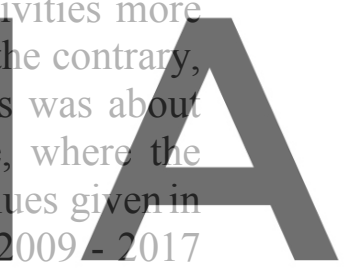

period by the Ministry of Industry and Trade listed in Table 1, it could be seen that within own

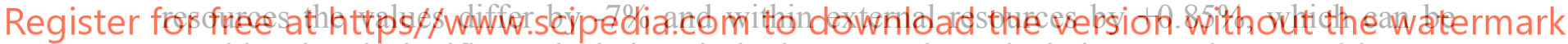
considered as insignificant deviations in both cases. These deviations can be caused by two factors, either a small sample for the research, or by several samples of one category of company size in the statistical survey of the Ministry of Industry and Trade, which affected the resulting values. It can be stated from the above analyses that the first golden rule of financing was almost observed for the medium-sized companies, however, not for small companies, where own resources are used more for financing and large companies, where external resources of financing are more used.

The second golden rule - the golden balance rule states that fixed assets should be covered by long-term resources (see Tables 5 and 7). 
Table 5. Representation of fixed assets in individual categories of companies.

\begin{tabular}{lcccccccccc}
\hline \multicolumn{1}{c}{ Year } & 2009 & 2010 & 2011 & 2012 & 2013 & 2014 & 2015 & 2016 & 2017 & Average \\
\hline Small & 40.09 & 33.95 & 41.94 & 39.69 & 32.30 & 39.28 & 40.39 & 35.08 & 31.15 & 37.10 \\
\hline Medium & 30.95 & 33.78 & 29.41 & 29.82 & 35.83 & 35.00 & 33.47 & 31.32 & 30.87 & 32.27 \\
\hline Large & 15.98 & 16.96 & 16.43 & 16.41 & 15.72 & 15.78 & 14.52 & 16.55 & 18.40 & 16.31 \\
\hline Average & 29.00 & 28.23 & 29.26 & 28.64 & 27.95 & 30.02 & 29.46 & 27.65 & 26.81 & 28.56 \\
\hline
\end{tabular}

Table 6. Representation of current assets in individual categories of companies.

\begin{tabular}{lcccccccccc}
\hline Year & 2009 & 2010 & 2011 & 2012 & 2013 & 2014 & 2015 & 2016 & 2017 & Average \\
\hline Small & 58.04 & 65.47 & 56.57 & 59.63 & 67.15 & 60.09 & 58.86 & 63.28 & 68.31 & 61.93 \\
\hline Medium & 67.78 & 65.24 & 70.10 & 69.77 & 63.89 & 64.67 & 66.09 & 68.36 & 68.75 & 67.18 \\
\hline Large & 84.26 & 84.90 & 86.19 & 86.51 & 87.14 & 86.35 & 86.53 & 86.67 & 84.63 & 85.91 \\
\hline Average & 70.03 & 71.87 & 70.95 & 71.97 & 72.72 & 70.37 & 70.49 & 72.77 & 73.90 & 71.67 \\
\hline
\end{tabular}

Table 7. Representation of long-term financial resources in individual categories of companies

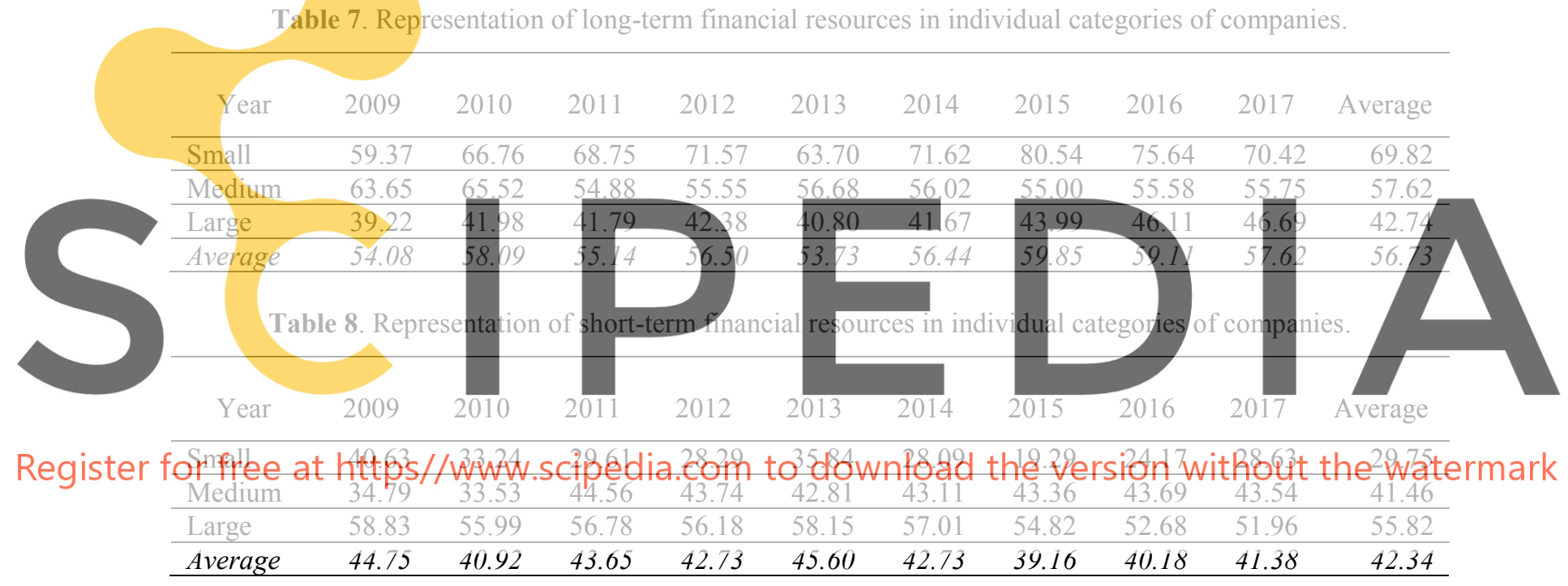

From the above-mentioned values (see Tables 5 and 7), it can be concluded that the second golden rule of financing was observed both in average values for all companies and for individual categories of company sizes.

In general, it can be stated that all companies had more current assets than long-term assets. A more significant difference in the share of fixed and current assets was in large companies, where it is clear that a larger financial volume is held in current assets, i.e. in inventories, receivables and cash, than in fixed assets. When comparing the resulting average values given in Table 5 and Table 6 with the average values calculated for the same period, i.e. 2009-2017 period by the Ministry of Industry and Trade from Table 2, it can be concluded that within fixed assets, the values differed by $-3.55 \%$ and within current assets by $+4.50 \%$, which can be considered as insignificant deviations in both cases. These deviations can similarly be caused by two factors, either by a small sample used in the research, or by more samples of one category of company size in the statistical survey of the Ministry of Industry and Trade, which 
would affect the resulting values.

Within the financial coverage of assets, long-term resources were used more in average values, which include share capital, profit or loss, funds, reserves, loans and liabilities with a maturity of more than 1 year. There was a more significant difference in small companies, where long-term resources were significantly more used, especially the positive economic result from previous years than short-term resources in the form of loans, credits or liabilities with a maturity of up to 1 year.

The third golden financing rule - golden "pari" rule states that fixed assets should be covered by equity (see Table 9).

Table 9. Average percentage share of fixed assets and equity for all analyzed companies.

\begin{tabular}{ccccccccccc}
\hline Year & 2009 & 2010 & 2011 & 2012 & 2013 & 2014 & 2015 & 2016 & 2017 & Average \\
\hline Fixed ass. & 29.00 & 28.23 & 29.26 & 28.64 & 27.95 & 30.02 & 29.46 & 27.65 & 26.81 & 28.56 \\
\hline Own res. & 43.36 & 48.61 & 47.24 & 48.44 & 46.58 & 48.35 & 50.51 & 46.55 & 46.14 & 47.31 \\
\hline
\end{tabular}

It is clear from the values that the third golden rule of financing is fulfilled in all cases. This is mainly due to the low volume of fixed assets in individual categories of company sizes and, conversely, the greater share of own sources of financing. Items from the balance sheet such as share capital, funds, economic result were taken into account as own sources of financing.

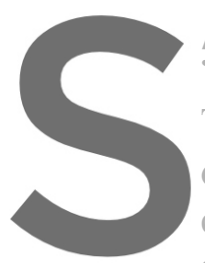

\section{Conclusions}

The aim of the pape

operating in the Czech

confirmation or rejection
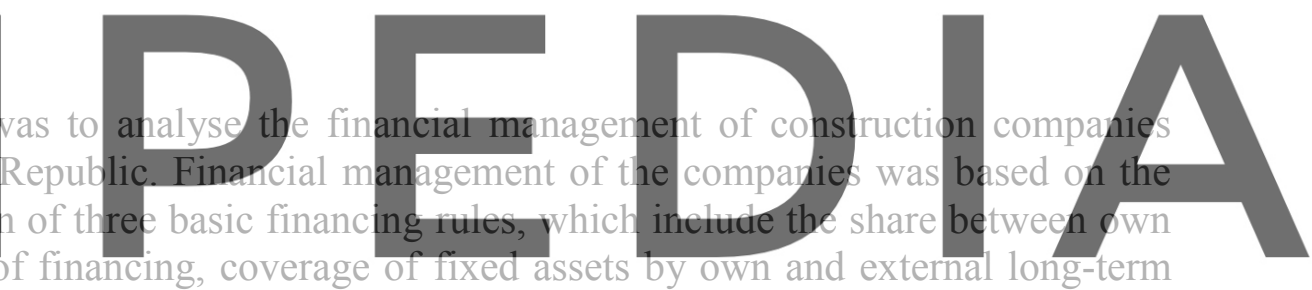

sources, and coverage of fixed assets only by own resources of financing. A financial analysis

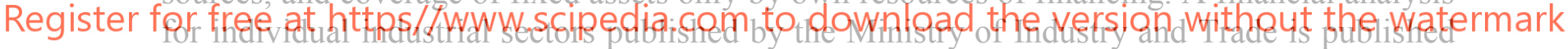

once a year within the framework of statistical surveys and analyses. The sector selected for the

research corresponded to the basic activities of the companies analysed, namely construction industry. However, the size of company is neglected in these analyses. Therefore, the research was focused on examining financial management according to the company size. It was concluded from the overall research survey that the second and third financing rules were confirmed for all company sizes, unlike the first rule on company indebtedness was almost confirmed for medium-sized companies. The analysis of indebtedness showed that small companies use own resources more for financing their activities and, conversely, large companies use external resources more for financing their activities.

This article represents a basic input into the overall investigation into the financial management of companies according to their size. Further research will be based on the investigation into the financial management of only fixed assets of companies with an impact on the economic result and in the next step the impact on taxation. The size of the company will be reflected in the subsequent research as well. 


\section{ORCID}

Jiř́ Kusák: https://orcid.org/0000-0002-1425-2001

Eva Vítková: http://orcid.org/0000-0002-2028-953X

\section{References}

Biliavska, A. V., Mizunska, I. R. and Kovalchuk, N. O. (2019). The Analytical Aspects of Management of the Liquidity Level and Solvency of Enterprises in the Energy Industry, Biznes Inform, Vol. 1(492), 255-261.

Biliavska, A. V., Mizunska, I. R. and Yurii, E. O. (2019). The Comparative Analysis of the Financial Performance of the JSC «Chernivtsioblenergo» and JSC «Lvivoblenergo», Biznes Inform, Vol. 6(497), 169-176. doi: 10.32983/2222-4459-2019-6-169-176.

Doporučení 2003/361/ES ze dne 6. května 2003.

Groneck, M. (2010). A golden rule of public finance or a fixed deficit regime? Economic Modelling, Vol. 27(2), 523-534, doi: 10.1016/j.econmod.2009.11.005.

Isik and Meric (2009). Public investment financing at European Union “Golden rule”, Ega Akademik bakis, Vol. 9(4), 1591-1603.

Kislingerová, E. (2007). Manažerské finance. Praha. C.H.Beck. ISBN 978-80-717-9903-0.

Konečný, Z. (2013). Golden Rules of Financing Relating to the life Cycle of Czech Automotive Firms, Journal of Competitiveness, Vol. 5(2),83-97, doi: 10.7441/joc.2013.02.06.

Srpová, J. and Řehoř, V. et al. (2010). Základy podnikání. Praha, Grada Publishing. ISBN 978-80-247-3339-5.

Vizslai, I. (2015). Assessing the Assets and Capital Structure in Different Forest Companies, Acta Facultatis Forestalis Zvolen.
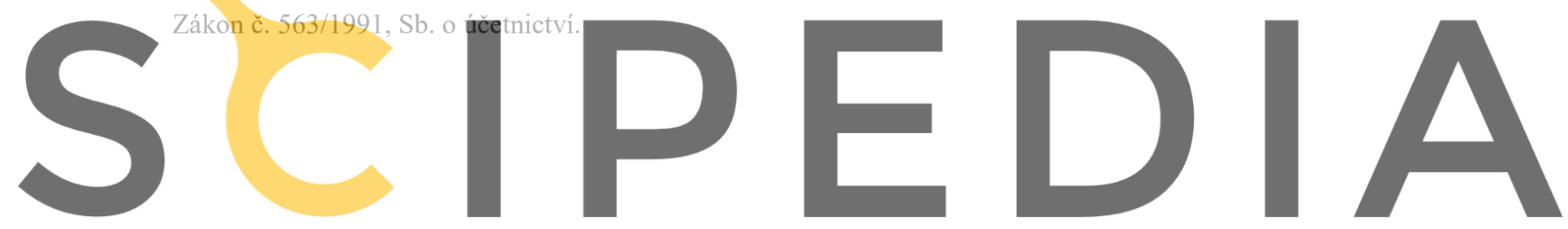

Register for free at https//www.scipedia.com to download the version without the watermark 